\title{
Counselling Services and Sustenance of Universal Basic Education (UBE) Programme in Public Secondary Schools in Calabar Municipality in Cross River State
}

Amalu, Melvina N. ${ }^{1}$

Abuo, Cyril B. ${ }^{2}$

David Bassey E. ${ }^{3}$

Dept. of Educational Foundations/Guidance and Counselling, University of Calabar, Calabar, Nigeria

\section{Doi:10.5901/jesr.2016.v6n1p47}

\section{Abstract}

Over the years, the public secondary schools in Calabar municipality in Cross River State, Nigeria were operating at the mercy of God. Little wonder the students after graduation faces a lot of educational, vocational and personal-social problems. This study investigated whether there is change now that there is the introduction of counseling services vis-à-vis the Universal Basic Education Programme. To carry out this investigation, two hundred respondents (certificated teachers) drawn from selected public secondary schools in the study area constituted the sample of the study. Pearson product moment correlation statistic at 0.05 level of significance with 198 degree of freedom was employed to analyze the data collected with a selfdesigned questionnaire - counseling services and Universal Basic Education Questionnaire (CSUBEQ). The result of hypothesis tested revealed a significant relationship between educational and vocational services and Universal Basic Education. However, it was found that little relationship exist between - social service and Universal Basic Education. The results were discussed and a conclusion was made. A number of useful recommendations were proffered.

Keywords: Counseling services, sustenance, universal, basic education

\section{Introduction}

Worldwide, education is the greatest investment any nation attempts to achieve as well as development of its resources both human and material. The purpose of education is closely related to the philosophy of a nation or a cultural environment. The school is seen as an agent of vocational placement. Holland (1959), asserts that people choose occupations that best suit their abilities, needs and interest which cannot be developed without the provision of counseling services namely, educational, vocational and personal -social services.

The Universal Basic Education can be said to lean on these counseling services. Counseling services are needed to assist individual in developing, and clarifying their educational, occupational and personal- social knowledge, and skills (Millan, 1990). The Nigerian Situation and Policy Analysis (SAPA, 1993) base line data on Basic Education began the definite research effort to offer education for all Nigerians in May 2000. The Universal Basic Education Scheme is structured along self-reliance through work.

Population report (1987) sees counseling as one person helping another as they talk face to face. This interaction although is said to be timid has deep implications. According to Herman and Grail (1967), counseling is the unique activity of the guidance services which assists in the acquisition and maintenance of a realistic self-concept. The particular function of the school counselor is to operate in the counseling setting for which he/she have specific preparation.

In this study, vital concepts will be emphasized. The paper will make conclusions depending on the findings arising from data analyzed. Equally, important and appropriate recommendations will be made.

\section{Counselling Services}

The scope of school counseling practices can be broken into three broad categories of services. These are;

1. Educational service

2. Vocational service 


\section{Personal-social service.}

Generally, counseling is a professional assistance that is given to a normal person who has a problem to understand himself and prepare for adjustment (Durojaiye, 1972). Basic Education in Nigeria shall be of 9 years durations comprising of 6 years of primary education and three years of junior secondary education (FGN, 2004). This level of education clearly stated shall be free and compulsory. It shall also include adult and non-formal education programmes especially at primary and junior education levels for the adult and out of school youths. Counselling services are important as education and vocational scenes are fast changing.

\subsection{Educational Service}

Educational problems top the list of students' problems in school. These include, grooming students to make effective subject choices in the school system so that they are assisted to pursue courses, which are best, suited to their interests, attitudes abilities, and so on, and so forth (Okorie and Ezeji, 1988). Students need to prepare for examination properly and to explore educational possibilities beyond their present educational level. Special efforts need to be made to help "first generation learners" that is, those students whose parents may never have gone to college or university to develop educationally.

\subsection{Vocational Service}

Vocational choice takes place as a result of a developmental process which has been traced to the early days of the individuals' life. Very often, this development can be traced to the influences exerted before birth. Like other aspects of counseling services, vocational service to the student is to make him become aware of the existing vocations in the labour market. Letting him to make appropriate choice of a vocation after school will help him develop autonomy in the world of work thereafter. The counselor can go to local industries and employment agencies to find out whether there some opportunities for employment of the would-be workers.

\subsection{Personal-Social Service}

This is another vital area of counseling students. Students face many personal problems related to themselves, their parents, friends, teachers, their educational achievement and social adjustment. Some of those personal- social problems re financial, sexual promiscuity, religious, low motivation, personality adjustment, cultism, inferiority complex, pilfering, fear, unrest, parental neglect, psycho-social problems to mention a few. The counsellor her is duty bound make himself available to the student. He should be an active adviser and helper to students individually and in groups. One learns a lot about students interests in such occasions.

\subsection{Universal Basic Education (UBE)}

In the year 1950, the universal declaration of Human Rights stated that "every one has a right to education". This declaration triggered effort from all countries of the world to universalize basic education. In Africa, at the Addis Ababa conference of 1961, African ministers of education set 1980 as the target year for African countries to achieve Universal Basic Education (Bonanni, 1978).

The emphasis on this type of education was also to develop illiterate men and women nomadic and to rehabilitate the physically challenged persons in the society (Asuquo, Inaja, David and Bassey, 2005). Basic education is the foundation for sustainable life-long learning. Its aims are to equip individuals with knowledge, skills and aptitudes that will enable the beneficiaries live meaning full lives. This educational programme is kept a float or sustained by the three major counseling services governments believe without which the universal basic education will collapse (Adejumo, Achebe and Okoye, 1990)

\subsection{Major Objectives of Universal Basic Education (UBE)}

The introduction of Universal Basic Education (UBE) some years back after universal primary education (UPE) was launched is an indication that, Universal Primary Education failed to yield the desired goal for which it was introduced. Universal Basic Education (UBE) had a new target date of 2010 to achieve 100 percent success. The major objectives of 
the new educational system include:

1. To universalize access to basic education in a conducive learning environment.

2. To develop in the entire citizenry a strong consciousness for education.

3. To eradicate illiteracy in Nigeria within the shortest possible time.

4. To provide free, compulsory universal basic education for every Nigerian child of school going age.

5. To reduce drastically drop out rate from the formal school system.

However, general and vocational continuing education is gaining in importance in the context of lifelong learning. Continuing education after completion of initial education accounts for the longest stage of life long learning, and should therefore be addressed to the longest segments of the population. These three education systems open new occupational and social opportunities at this time of radical social, economic, political and even spiritual changes in Nigeria.

\section{Research Methodology}

The study aims at investigating whether counseling services determine the sustainability of universal basic education in Calabar municipality in Cross River State. The basic sample comprises two hundred (200) subjects, 100 are males and 100 are females. The study adopted purposive sampling technique to select the subjects. Only certificated graduates teachers were used in this study

\section{Instrumentation}

A survey questionnaire, counselling services and sustenance of universal basic education questionnaire (CSUBEQ) was developed and constructed by the researchers for data collection. The instrument consisted of two parts, A and B. Part A was used to elicit respondents' demographic information on sex, age marital status, occupation, state of origin and qualification. Par B was a 20 item, 4 points Likert scale that measured three different counselling services. The instrument had content validity based on the opinions and approval of experts. The value of the reliability coefficient of the three sub-scale of the instrument was high enough to warrant the use of the instrument in the study. The reason for this method is to limits the researcher ability of having direct control over the variables.

\section{Data Analysis And Result}

Data obtained was analyzed using the appropriate test statistics, below is an all-embracing hypothesis formulated to guide the study.

Hypothesis: Counselling services do not significantly relate to sustenance of universal basic education in Calabar Municipality. To test this hypothesis, Pearson product moment correlation coefficient statistic was used. A summary of the result is shown in table one below.

Table 1: Pearson product moment correlation analysis of the relationship between counseling services and universal basic education $(\mathrm{N}=200)$

\begin{tabular}{cccccc}
\hline S/No & Variable & $\sum X \sum Y$ & $\sum X^{2} \sum Y^{2}$ & $\sum X Y$ & $r$-Value \\
\hline 1 & Educational service & $(\mathrm{x}) 234$ & 6124 & 2636 & 0.85 \\
2 & Vocational services & $(\mathrm{x}) 840$ & 3772 & 3014 & 0.94 \\
3 & Personal-soc. Service & $(\mathrm{x}) 420$ & 1886 & 1532 & 0.061 \\
$* \mathrm{P}<0.05 ; \mathrm{df}=198 ;$ critical $\mathrm{r}$-value $=0.164$ & 522 & 7218 & 3434 & 0.75 \\
\cline { 2 - 6 }
\end{tabular}

As shown in table 1, the r-values of $0.85,0.94$ and 0.75 were obtained at 0.05 level of significance with 198 degrees of freedom. The values above were found to be greater than the critical r-value of 0.164 . These results therefore show that there is a significant relationship between universal basic education and educational and vocational service. This implies that other sub-variables will lead to the enhancement and development of universal basic education except personalsocial service. 


\section{Discussion}

The finding of this study revealed that there was positive significant relationship between educational and vocational services with universal basic education in public schools in Calabar municipality. The findings agree with previous related findings of Crow and Crow (1997), who stated that the preparation of the members of a society for life involves the education and counselling of the young members of the community. In doing this, education is used to develop some basic skills in the individuals so that they will in the future be engaged in a profitable and satisfying career which can match their potentialities and interest.

On the other hand, the report of this study has shown that, personal-social service of counselling cannot facilitate the rapid improvement of universal basic education in the study area. The researcher agrees with this finding because proper sanitization of the area is lacking. Some students face so many awkward situations at school. They find it difficult to get out of undesirable practices. No arrangement is made to assist students to have reasonable estimate of selfesteem to actualize their potential (Durojaiye, 1976). This result has also shown that enough counselling is not given to the students in the study area.

From the findings, it could be asserted that, counselling is synonymous with education and as such, the Universal Basic Education will certainly depend on counselling services Shertzer and stone (1981), sees the concept of counselling services as developmental process which stresses help to all students in all areas of their vocational, educational and personal-social experiences at all stages of their lives. The result of this research has however, not agreed with their findings.

\section{Conclusion}

Based on the findings, it is evident that, the future of Universal Basic Education is bright in Calabar Municipality in Cross River State, Nigeria. It is important to warn here that, to sustain the education system, both professionals and teacher counsellors should leave no stone unturned in the area of adequate provision of counselling services namely; educational, vocational and personal-social services.

Besides the moral and personal9social aspects of counselling that are not given adequate attention, the educational and vocational areas have yielded enough impact on the educational and vocational development in Calabar Municipality. This does not imply that, there is a beef up efforts to sanitize the almost forgotten counselling service as it deals directly with the affective domain of each individual student.

\section{Recommendations}

From the findings of this study, the following recommendations are made;

1. For functional and sustainable Universal Basic Education in the study area, the honourable commissioner of education should use his good office to liaise with the chairman of State Education Board to post professional counselors to public secondary schools in Calabar Municipality.

2. All the principals of the public secondary schools in the study area should be organizing career days to enhance students' career awareness. It is true that every vocation requires a reasonable level of educational and personal-social where-withal. This is so, as counseling services afford students with the ability for all round development.

3. Government of the state should help improve the dilapidated socio=economic backgrounds of students' parents to enable them provide their children and wards with recommended materials for effective learning.

4. Students on their part should realize that their attitudes tell their personal-social stories. They should at all times behave like future leaders and not as fugitives and vagabonds. They have to co-operate with their parents, constituted authorities government, and their school personnel to attract the dividends of education.

5. The idea of boarding system in our secondary schools should be considered a major education priority in the research area. With the system well-articulated, students will live together and avail themselves of the opportunities of reading together working and learning good and approved attitudes together.

\section{References}

Asuquo, P. N., Inaja, A. E., David, B. E., and Bassey P. U., (2005). Historical Foundations of Education in Nigeria. Calabar; University of Calabar Press. 
Bonnani, C., (1978). Fundamental and Basic Education: Some Differences, Ibadan: Literacy Work Publishers.

Crow, L. D. and Crow, A., (1997). An Introduction to Guidance Principles and Practices. New York: American Books.

Durojaiye, M. O. A., (1972). Psychological Guidance of the School Child. Ibadan: Evans Brothers Publishers.

Federal Government/UNICEF (1993). Situation and Policy Analysis of Basic Education in Nigeria (SAPA):National Report. Lagos: Federal Ministry of Educational Youth Development.

Federal Republic of Nigeria (2004). National Policy on Education, Lagos: NERDC Press.

Herman, J. P. and Gail, F. F., (1967) Guidance: A Developmental Approach (2nd ed) Chicago: McNally Publishers.

Holland, J. L., (1959). A theory of Vocational Choice. Journal of Counselling Psychology, 6(4), 35-45.

Mallam P. M. (1990). Guidance and Counselling in Secondary Schools. Ibadan: Evans Brothers Publishers.

Okorie, J. U. and Ezeji, S. C. A., (1988) Elements of Guidance, Vocational and Career Education. Onitsha: Summer Educational Publishers.

Population Reports (1987). Counselling Guide. Baltimore: the Johns Hopkins University Press.

Shertzer, B. \& Stone, S. C., 1980. Fundamentals of guidance (4th ed.) Boston: Houghton Difflin Publishers. 